DOI: $10.31073 / \mathrm{mivg} 201801-118$

Available (PDF): http://mivg.iwpim.com.ua/index.php/mivg/article/view/118

УДК 556.53

\title{
ПРОСТОРОВО-ЧАСОВА ОЦНКА ЯКОСТІ ВОД ЗА ЕКОЛОГІЧНИМИ КРИТЕРІЯМИ В СИСТЕМІ КАНАЛУ ДНІПРО-ДОНБАС
}

B.I. Рожко,

Інститут водних проблем і меліорації НААН, Київ, Україна; e-mail: victoria_ro@ukr.net

Анотація. У статті наведено порівняльний аналіз якості вод за «Методикою екологічної оцінки якості поверхневих вод за відповідними категоріями» за період до та після проведення водообміну у каналі Дніпро-Донбас. Встановлено, що основними показниками, які погіриують якість вод у иьому каналі, є підвицений вміст сульфатів (7 категорія) та величина показника прозорості(б-7 категоріі). За даними показниками води характеризуються за станом як «погані» та «дуже погані», а за ступенем чистоти як «брудні» та «дуже брудні».

Ключові слова: екологічна очінка, якість вод, клас якості вод, категорія якості вод, індекс якості вод.

Вступ. Води каналу Дніпро-Донбас $є$ одним із джерел водопостачання для потреб міста Харків та області, а також для зрошення та підтримки водності річки Сіверський Донець [1]. До того ж канал повинен забезпечити достатню кількість води відповідної якості для потреб питного водопостачання, яка залежить від природних факторів іï формування та характеризується підвищеними показниками жорсткості води річок і струмків, що впадають у нього [2].

Аналіз попередніх досліджень. Перші роботи, присвячені дослідженню хімічного складу води на території України, були проведені в кінці XIX ст., коли розвиток промисловості і ріст великих міст викликали необхідність вивчення річкових вод для використання в промисловості та водозабезпечення міст. Але існуючі дані були неповними. Вони становили собою одиничні аналізи, проведені у різний час для різних басейнів [3].

Гідрохімічний аналіз якості води в період до будівництва каналу Дніпро-Донбас у заплаві р. Оріль наведено в [4]. Згідно 3 отриманими даними вода належить до сульфатного класу натрієвої групи другого типу. Якість води каналу, в контексті поверхневих вод басейну р. Дніпро, розглянута $[5,6,7]$.

Різними вченими проводиться аналіз якості води у каналі Дніпро-Донбас для комунально-питного призначення $[2,8]$ та на зрошення.

Матеріали та методика досліджень. Для екологічної оцінки ефективності проведення водообміну пропонується екосистемний підхід, що базується на використанні нейронної мережі [9]. Для адекватної розробки нейронної мережі та візуалізації екологічної оцінки на вибраному об'єкті необхідно розробити карту-схему 3 нанесенням пунктів відбору проб (рис. 1).

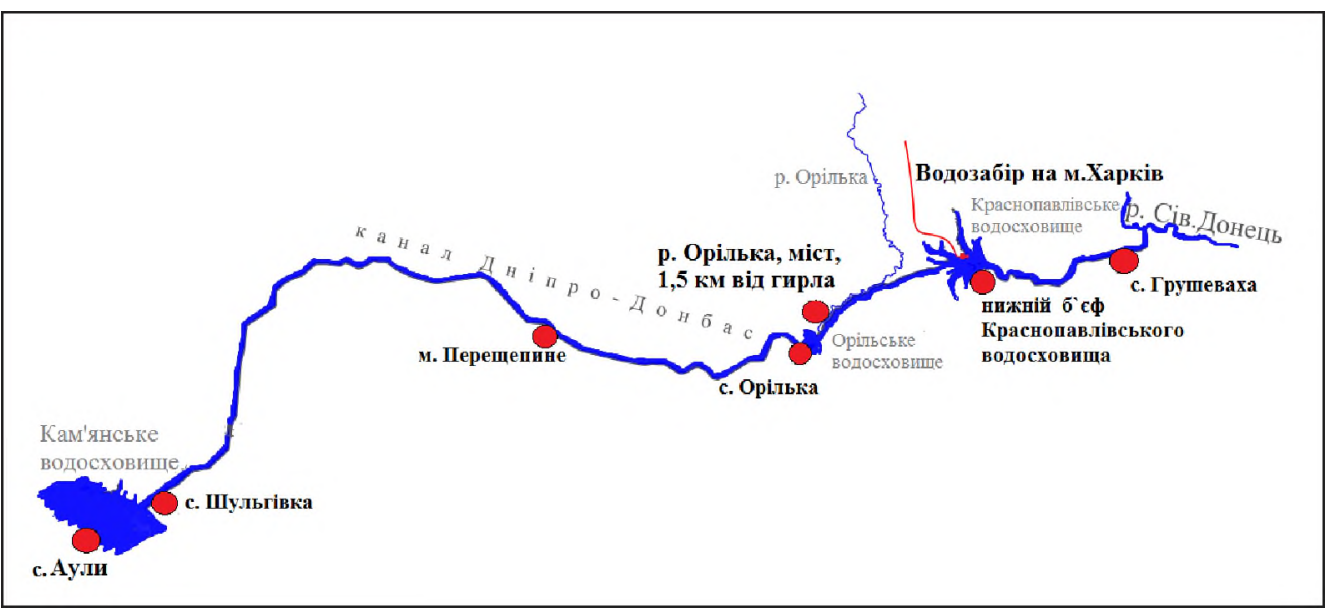

Рис. 1 Карта-схема пунктів спостережень у каналі Дніпро-Донбас та Кам'янське водосховище 
Мета і завдання досліджень. Головною метою $є$ з'ясування тенденцій змін якості вод у системі каналу Дніпро-Донбас до та після проведення водообміну. Для цього необхідно виконати екологічну оцінку якості вод за відповідними критеріями згідно 3 [10], яка надає інформацію про воду як складову водної екосистеми і важливу частину природного середовища людини.

Результати дослідження та їх обговорення. На основі єдиних екологічних критеріїв проведена оцінка змін стану водних ресурсів та виконано порівняльний аналіз якості вод на окремих ділянках каналу Дніпро-Донбас при проведенні водообміну у 2016 р. відповідно до Методики [10]. Дослідження проводилися за трьома блоками спеціалізованих класифікацій: блок сольового складу, блок трофо-сапробіологічних критеріїв та блок специфічних речовин токсичної та радіаційної дії, за середніми та максимальними (найгіршими) значеннями показників двох періодів: серпень-вересень (до водообміну) і грудень-січень (після проведення водообміну) [10].

У період досліджень до проведення водообміну, відповідно до [10] на першому рівні ієрархії, оцінка якості вод за першим блоком (сума іонів, хлориди, сульфати), розрахунок за індексами сольового складу $\left(\mathrm{I}_{1 \text { сер }}, \mathrm{I}_{1 \max }\right)$, показала, що вода каналу Дніпро-Донбас за середніми і найгіршими величинами Il знаходиться в межах $1,0 \leq \mathrm{I}_{1} \leq 6,3$.

Величина мінералізації у каналі розподілена нерівномірно, спостерігається іiі збільшення від с. Шульгівка (312 мг/дм³) і до с. Орілька (2767 мг/дм³) та у р. Орілька $(2067$ мг/дм³), що впадає в канал у районі Орільського водосховища. За критерієм мінералізації переважна більшість вод каналу належить до 1-3 категорії I-III класів.

Води характеризуються як перехідні за якістю від (посередніх), (помірно забруднених» до «поганих», «брудних» за $\mathrm{I}_{1 \text { cep }}$ та «поганих», «брудних» за $\mathrm{I}_{1 \max }$. Максимальні значення блокових індексів сольового складу iз встановленим значенням $\left(\mathrm{I}_{1 \max }=5,0-6,0\right)$ зафіксовано на ділянці від Орільського до Краснопавлівського водосховища. При цьому найгіршими виявилися значення показника сульфатів, величини яких коливаються у межах від 34,4 до 1222,2 мг/дм ${ }^{3}$. Значення індексів трофо-сапробіологічних (еколого-санітарних) показників змінюються в межах: для середніх значень $3,0 \leq \mathrm{I}_{2 \text { сер }} \leq 3,7$; для максимальних $3,1 \leq \mathrm{I}_{2 \max } \leq 4,2$.

За класифікацією води каналу ДніпроДонбас належать до 2-го та 3-го класів 3-і та 4-ї категорії і характеризуються як «добрі», «досить чисті), перехідні за якістю від «добрих», «досить чистих» до «задовільних», «слабо забруднених», і «задовільні», «слабо забруднені». Найгірші значення за трофо-сапробіологічним блоком зафіксовано за показником прозорості (5 клас, 7 категорія), а у пункті спостережень р. Орілька, міст, 1,50 км від гирла, - за показником фосфору фосфатів (5 клас, 7 категорія) та розчиненого кисню (4 клас, 6 категорія) .

Значення середнього та максимального індексів специфічних показників токсичної i радіаційної дії коливаються в межах $2,50 \leq \mathrm{I}_{3 \mathrm{cep}, \text { max }} \leq 3,50$. Води каналу належать до 2-го класу 2-ї та 3-ї категорій і характеризуються як «добрі», «досить чисті»).

На другому рівні ієрархії проведена оцінка за блоковими індексами класів та катепорій вздовж каналу Дніпро-Донбас, яка показала високий рівень забруднення за сольовим блоком, зокрема за показником сульфатів (7 категорія), та за показником прозорості (7 категорія) трофосапробіологічного блоку [11].

На третьому рівні ієрархії в результаті осереднення відбувається подальше пониження рівня забруднення за зведеними екологічними індексами до 2-4 категорій II-III класів.

У системі каналу якість вод змінювалася від «дуже добрих», «чистих» 3 тенденцією наближення до категорії «добрих», «досить чистих》 (с. Шульгівка) до “задовільних», «слабо забруднених» вод з тенденцією наближення до «посередніх», «помірно забруднених) (Орільське та Краснопавлівсыке водосховища) (рис. 2).

Результати розрахунків до проведення водообміну у Краснопавлівському водосховищі наведено у табл. 1.

У період після проведення водообміну в каналі спостерігається пониження концентрації (мг/дм³) середніх та максимальних значень показників блоку сольового складу. За показником суми іонів та хлоридів якість вод на ділянці від с. Шульгівка до с. Орілька належить до 1 категорії 1 класу якості, а на ділянці від Орільського водосховища і до скиду у р. Сіверський Донець - до 3 і 4 категорій 3 класу якості. Однак за величиною вмісту сульфатів якість води на ділянці від Орільського до Краснопавлівського водосховища залишається в межах 7 категорії 5 класу.

Синхронно із зниженням концентрації значень показників блоку сольового складу відбувається зниження концентрацій значень показників трофо-сапробіологічного блоку 


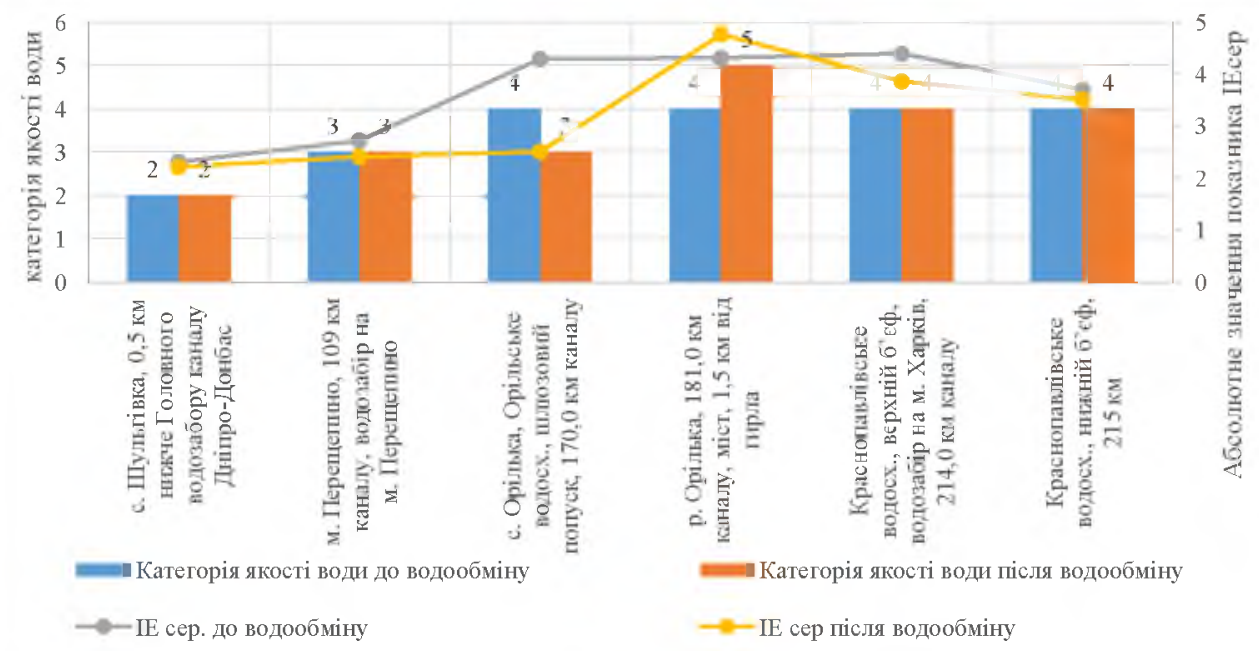

Рис. 2. Категорії якості води та абсолютні значення показника $\mathbf{I}_{\text {Eсер. }}$ до водообміну та після його проведення

1. Оцінка класів, категорій та субкатегорій якості води,

ії вербальна екологічна оцінка за середнім значенням блокових індексів у системі каналу Дніпро-Донбас у період до проведення водообміну

\begin{tabular}{|c|c|c|c|c|c|c|}
\hline $\begin{array}{l}\text { Місце відбору } \\
\text { проби }\end{array}$ & 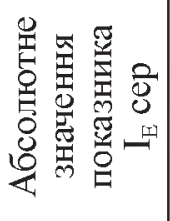 & 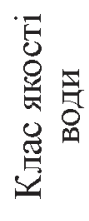 & 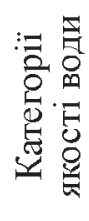 & 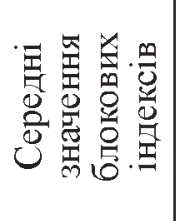 & 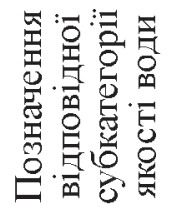 & $\begin{array}{l}\text { Словесна характеристика } \\
\text { субкатегорій якості води }\end{array}$ \\
\hline $\begin{array}{c}\text { с. Шульгівка, } \\
0,5 \text { км нижче } \\
\text { Головного водо- } \\
\text { забору каналу } \\
\text { Дніпро-Донбас }\end{array}$ & 2,31 & 2 & 2 & $2,26-2,50$ & $2(3)$ & $\begin{array}{c}\text { «Дуже добрі»), (чисті» води } \\
\text { з тенденцією наближення } \\
\text { до категорії «добрих», } \\
\text { «досить чистих» }\end{array}$ \\
\hline $\begin{array}{c}\text { м. Перещепино, } \\
109 \text { км каналу, } \\
\text { водозабір на } \\
\text { м. Перещепино }\end{array}$ & 2,72 & 2 & 3 & $2,51-2,75$ & $2-3$ & $\begin{array}{c}\text { Води перехідні за якістю } \\
\text { від «дуже добрих», } \\
\text { «чистих» до «добрих», } \\
\text { «досить чистих») }\end{array}$ \\
\hline $\begin{array}{c}\text { с. Орілька, } \\
\text { Орільське водосх., } \\
\text { шлюзовий попуск, } \\
170,0 \text { км каналу }\end{array}$ & 4,29 & 3 & 4 & $4,26-4,50$ & $4(5)$ & $\begin{array}{c}\text { «Задовільні»), «слабо } \\
\text { забруднені» води з тенден- } \\
\text { цією наближення до } \\
\text { «посередніх», «помірно } \\
\text { забруднених» }\end{array}$ \\
\hline $\begin{array}{l}\text { p. Орілька, } \\
181,0 \text { км каналу, } \\
\text { міст, 1,5 км від } \\
\text { гирла }\end{array}$ & 4,31 & 3 & 4 & $4,26-4,50$ & $4(5)$ & $\begin{array}{c}\text { «Задовільні», «слабо } \\
\text { забруднені» води з тенден- } \\
\text { цією наближення до } \\
\text { «посередніх», «помірно } \\
\text { забруднених» }\end{array}$ \\
\hline $\begin{array}{c}\text { Краснопавлівське } \\
\text { водосх., верхній } \\
\sigma^{\prime} є ф, \text { водозабір на } \\
\text { м. Харків, } \\
214,0 \text { км каналу } \\
\end{array}$ & 4,39 & 3 & 4 & $4,26-4,50$ & $4(5)$ & $\begin{array}{c}\text { «Задовільні», «слабо } \\
\text { забруднені» води з тенден- } \\
\text { цією наближення до } \\
\text { «посередніх», «помірно } \\
\text { забруднених» }\end{array}$ \\
\hline $\begin{array}{c}\text { Краснопавлівське } \\
\text { водосх., нижній } \\
\sigma^{\prime} є ф, 215 \text { км }\end{array}$ & 3,70 & 3 & 4 & $3,51-3,75$ & $3-4$ & $\begin{array}{c}\text { Води, перехідні за якістю } \\
\text { від «добрих», «досить } \\
\text { чистих» до «задовільних», } \\
\text { «сслабоо забруднених» }\end{array}$ \\
\hline
\end{tabular}


та блоку специфічних речовин токсичної дії, але категорії якості залишаються таким ж як до проведення водообміну. Після проведення водообміну води каналу Дніпро-Донбас насичені киснем і за цим показником відповідають 1 категорії 1 класу якості, в той же час за показником прозорості - 6-7 категорії 4-5 класу якості (табл. 2).

Річка Орілька перетинає канал ДніпроДонбас у районі Орільського водосховища і має природну, характерну для Харківської області та Донбасу, високу жорсткість води більше 16 мг-екв./дм³ . Річка маловодна, середні річні витрати коливаються в межах 0,20-0,40 $\mathrm{m}^{3} / \mathrm{c}$, у весняну повінь досягають $12,0-13,0 \mathrm{~m}^{3} / \mathrm{c}$, у літню межень часто пересихає, в зимову - перемерзає. Окрім високої жорсткості, води Орільки суттєво забрудненні за сольовим блоком, зокрема за показниками суми іонів і сульфатів відносяться до 7 кате- горії 5 класу, а за хлоридами - до 5-6 категорії 3-4 класів. Накопичення сульфатів у воді р. Орілька зумовлено впливом широко розповсюджених гіпсовмісних порід в четвертинних і неогенових відкладах басейну і солончакових грунтів. Мінералізація води в пункті спостереження на $p$. Орілька в період дослідження становила 2,0-3,4 г/дм³ 3 класу якості води.

За показниками прозорості, перманганантної окиснюваності, вмісту розчиненого кисню та фосфатів трофо-сапробіологічного блоку якість води належить до 6-7 категорій 4-5 класів.

Під час проведення водообміну у каналі Дніпро-Донбас рівні води підвищуються і на ділянці від впадіння р. Орілька в Орільське водосховище до пункту спостережень на відстані 1,5 км можуть спостерігатися явища зворотної течії. У результаті до річки надхо-

\section{2. Оцінка класів, категорій та субкатегорій якості води,}

ії вербальна екологічна оцінка за середнім значенням блокових індексів у системі каналу Дніпро-Донбас у період після проведення водообміну

\begin{tabular}{|c|c|c|c|c|c|c|}
\hline $\begin{array}{c}\text { Місце відбору } \\
\text { проби }\end{array}$ & 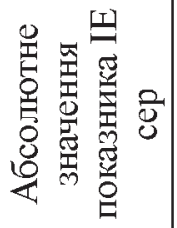 & 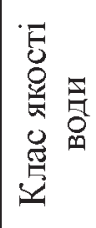 & 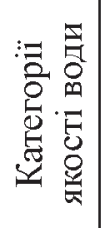 & 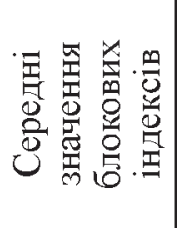 & 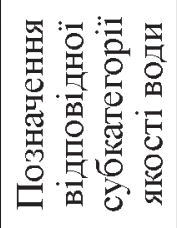 & $\begin{array}{l}\text { Словесна характеристика } \\
\text { суб́категорій якості води }\end{array}$ \\
\hline $\begin{array}{c}\text { с. Шульгівка, } \\
0,5 \text { км нижче } \\
\text { Головного водо- } \\
\text { забору каналу } \\
\text { Дніпро-Донбас } \\
\end{array}$ & 2,21 & 2 & 2 & $2,00-2,25$ & 2 & «Дуже добрі », «чисті» води \\
\hline $\begin{array}{c}\text { м. Перещепино, } \\
109 \text { км каналу, } \\
\text { водозабір на м. } \\
\text { Перещепино } \\
\end{array}$ & 2,41 & 2 & 3 & $2,26-2,50$ & $2(3)$ & $\begin{array}{c}\text { «Дуже добрі», «чисті» води } \\
3 \text { тенденцією наближення } \\
\text { до категорії «добрих», } \\
\text { «досить чистих» } \\
\end{array}$ \\
\hline $\begin{array}{c}\text { с. Орілька, } \\
\text { Орільське водосх., } \\
\text { шлюзовий попуск, } \\
170,0 \text { км каналу } \\
\end{array}$ & 2,51 & 2 & 3 & $2,51-2,75$ & $2-3$ & $\begin{array}{c}\text { Води перехідні за якістю } \\
\text { від «дуже добрих», } \\
\text { «чистих» до «добрих», } \\
\text { «досить чистих») } \\
\end{array}$ \\
\hline $\begin{array}{l}\text { p. Орілька, } 181,0 \\
\text { км каналу, міст, } 1,5 \\
\text { км від гирла }\end{array}$ & 4,76 & 4 & 5 & $4,51-4,75$ & $4-5$ & $\begin{array}{c}\text { Води перехідні за якістю } \\
\text { від «(задовільних»), } \\
\text { «слабо забруднені») до } \\
\text { «посередніх», «помірно } \\
\text { забруднених») }\end{array}$ \\
\hline $\begin{array}{c}\text { Краснопавлівське } \\
\text { водосх., верхній } \\
\sigma^{\prime} є ф, \text { водозабір на } \\
\text { м. Харків, 214,0 } \\
\text { км каналу }\end{array}$ & 3,86 & 3 & 4 & $3,76-3,99$ & $4(3)$ & $\begin{array}{l}\text { «(Задовільні», «слабоза- } \\
\text { бруднені» води з ухилом до } \\
\text { «добрих», «досить чистих» }\end{array}$ \\
\hline $\begin{array}{c}\text { Краснопавлівське } \\
\text { водосх., нижній } \\
\text { б'єф, } 215 \text { км }\end{array}$ & 3,51 & 3 & 4 & $3,51-3,75$ & $3-4$ & $\begin{array}{c}\text { Води перехідні за якістю } \\
\text { від «добрих», «досить } \\
\text { чистих» до «(задовільних», } \\
\text { «слабо забруднених». }\end{array}$ \\
\hline
\end{tabular}


дять води кращої за класом якості. Але це явище триває лише в період водообміну, після закінчення якого р. Орілька знов несе забруднені води до водосховища.

На ділянці каналу від Краснопавлівського водосховища до водоскиду у р. Сіверський Донець вода йде самопливом, частково використовуючи русла річок Берека i Бритай. Останній екологічний водовипуск до Сіверського Донця здійснювався під час водообміну у листопаді-грудні 2013 р., тому до загальної оцінки якості вод при проведенні водообміну у 2016 р., якість вод самопливної ділянки не включається.

Висновки. За результатами порівняльного аналізу стану водних ресурсів до та після проведення водообміну у каналі ДніпроДонбас встановлено покращення якості вод у період після проведеного водообміну на ділянці каналу від с. Шульгівка до Орільського водосховища від 《добрих», «досить чистих» та «задовільних», «слабо забруднених» до «дуже добрих», «чистих» з тенденцією наближення до категорії «добрих», «досить чистих».

Проведені дослідження показують зменшення значення екологічного індексу $\mathrm{I}_{\mathrm{E}} \mathrm{y}$ Краснопавлівському водосховищі та покращення якості вод від перехідних за якістю від (〈добрих», (〈досить чистих) до «задовільних), «слабо забруднених» до категорії («добрі», «досить чисті».

За результатами проведених розрахунків екологічної оцінки якості вод за трьома блоками показників виявлено забруднюючі речовини, якість води за якими відноситься до шостої і сьомої категорії. Систематично високий рівень забруднення вод у системі каналу встановлено за вмістом сульфатів та показником прозорості. Води каналу Дніпро-Донбас за встановленими показниками характеризуються за станом як 〈погані» та «дуже погані», а за ступенем чистоти як «брудні») та («дуже брудні» [11].

\section{Бібліографія}

1. Бережсий I. Водообмін на Краснопавлівському водосховищі // Слобідський край, 2012. №84. C. 3 .

2. Рожко В.І., Ковальчук П.І. Аналіз якості води для питного водопостачання в системі каналу Дніпро-Донбас // Меліорачіл і водне господарство. 2016. № 103 С. 32-36.

3. Притула Л. М. Особливості формування хімічного складу поверхневих вод басейну р. Десни у 2000-2007 роках // Гідрологія, гідрохімія і гідроекологія: 2010. Т. 18. С. 230-237.

4. Коненко А.Д. Гидрохимическая характеристика мальх рек УССР / Киев: Изд-во АН УССР, 1952. $172 \mathrm{c}$.

5. Осадчий B.I. Основні тендениї̈ формування хімічного складу поверхневих вод Украӥни у 1995-1999 рр. // Наукові праці Українського науково-дослідного гідрометеорологічного інстиmymy. 2001. Bun. 248. C. 138-153.

6. Осадча Н.М., Осадчий В.I. Особливості формування хімічного складу поверхневих вод Украйни у 2000 р. /Гідрологія, гідрохімія і гідроекологія. Київ: Ніка-Центр, 2001. С. 379-389.

7. Горсв, Л.М., Пелещенко В.І., Хільчевський В.К. Гідрохімія Украйни : підручник / Київ: Вища икола, 1995. С. 308.

8. Ричак Н.Л., Чепурна А.О. Склад та якість питної води різних джерел водопостачання (на прикладі Дзержсинського району міста Харкова) // Вісник КрНУ ім. Михайла Остроградського. 2012. Bun. 6 (77). C. 112-117.

9. Kovalchuk P.I. Perceptron model of system environmental assessment of water quality in river basins / P.I. Kovalchuk, A.V. Gerus, V.P. Kovalchuk // 4-th international conference on inductive modeling. Proceedings. Kyiv. 2013. P. 279-284.

10. Методика екологічної очінки якості поверхневих вод за відповідними категоріями В.Д. Романенко та ін. Київ: Символ-Т, 1988. С. 28.

11. Рожко В.І. Екологічна очінка якості вод у каналі Дніпро-Донбас при проведенні водообміну // Роль меліорачії та водного господарства у забезпеченні сталого розвитку землеробства: III Міжнар. наук.-практ. конф. мол. учених: тези доп. Київ: ІВПіМ, , 6 грудня 2017 р. C. 60-63.

\section{References}

1. Berezhnyi, I. (2012). Vodoobmin na Krasnopavlivskomu vodoskhovyshchi. [The water exchange at the Krasnopavlivske reservoir] Slobidskyi krai 84, 3.

2. Rozhko, V. I., \& Kovalchuk, P. I. (2016). Analiz yakosti vody dlia pytnogo vodopostachanniav systemi kanalu Dnipro-Donbas. [The analysis of the water quality for drinking water supply in the Dnipro-Donbas canal system] Melioraciya i vodne gospodarstvo, 103, 32-36. [in Ukrainian]. 
3. Prytula, L.M. Osoblyvosti formuvannia khimichnogo skladu poverkhnevyh vod baseinu r. Desny $v$ 2000-2007 rokah. TThe formation features of the chemical composition of surface waters at the Desna river basin in 2000-2007yy.] Hidrologiya, gidrokhimiya i hidroekologiya, T. 18, 230-237. [in Ukrainian].

4. Kononenko, A. D. (1952) Hidrokhimicheskaia kharakteristika malykh rek USSR. [Hydrochemical characteristics of small rivers of the USSR] Kiev: AN USSR. [in Russian].

5. Osadchyi, V.I. (2001) Osnovni tendenciyi formuvannia khimichnogo skladu poverkhnevyh vod Ukrainy $v$ 1995-1999 rokah. The main trends in the formation of chemical composition of the Ukraine surface waters in 1995-1999 yy.J Naukovi praci Ukrainskogo naukovo-doslidnogo hidrometeorologichnogo instytutu, 248, 138-153. [in Ukrainian].

6. Osadcha, N. M., \& Osadchyi, V.I. (2001) Osoblyvosti formuvannia khimichnogo skladu poverkhnevyh vod Ukrainy $v 2000 \mathrm{r}$. [The formation features of the chemical composition of the Ukraine surface waters in 2000J Hidrologiya, gidrokhimiya i hidroekologiya, Kyiv: Nika-Tsentr, 379-389. [in Ukrainian].

7. Horev, L. M., \& Peleshenko, V. I., Khilchevskyi, V. K. (1995) Hidrokhimia Ukrainy: pidruchnik. [The hydrochemistry of Ukraine] Kyiv: Vyshcha shkola. [in Ukrainian].

8. RychakN. L., \& ChepurnaA. O. (2012) Sklad tayakist pytnoi vody riznyhdzherel vodopostachannia (na prykladi Dzerzhynskogo rayonu mista Kharkova). [The composition and quality of drinking water of various sources of water supply (on the example of the Dzerzhinsky district of the Kharkiv city)] Visnyk KrNU im. Mykhaila Ostrohradskoro, 6(77), 112-117. [in Ukrainian].

9. Kovalchuk, P.I., \& Gerus, A.V., Kovalchuk, V.P. (2013) Perceptron model of system environmental assessment of water quality in river basins. IV intern. Conf. on inductive modeling. Proceedings. Kyiv., 279-284. [in Ukrainian].

10. Romanenko, V.D. (1988) Metodyka ekolohichnoi otsinky yakosti poverkhnevykh vod za vidnovidnymy kategoriyamy. [The methodology of ecological assessment of surface water quality according to the relevant categories] Kyiv: Symvol-T, 28. [in Ukrainian].

11. Rozhko, V. I. Ekolohichna otsinka yakosti vod v kanali Dnipro-Donbas pry provedenni vodoobminu [The ecological assessment of water quality in the Dnipro-Donbas canal during the water exchange] (2017, December 7) Rol melioratsii ta vodnogo hospodarstva v zabezpechenni staloho rozvytku zemlerobstva: III Mizhn. nauk.-prakt. konf. mol. uchenikh: tezy dop. Kyiv: IVPIM., 60-63. [in Ukrainian].

В.И. Рожко

Пространственно-временная оценка качества вод по экологическим критериям в системе канала Днепр-Донбасс

В статье приведен сравнительный анализ качества вод по "Методике экологической оченки качества поверхностных вод по соответствующим категориям» за период до и после водообмена в канале Днепр-Донбасс. Установлено, что основными показателями, которые ухудиают качество вод в этом канале, являются повыненное содержание сульфатов (7 категория) и величина показателя прозрачности (6-7 категории). Данные показатели характеризуют воды по состоянию как «плохие» и «очень плохие», а по степени чистоты как «грязные» и«очень грязные».

Spatial-temporal estimation of water quality according

V.I. Rozhko to ecological criteria in the Dnipro-Donbass canal system

The article gives a comparative analysis of the quality of water according to the «Methodology of environmental assessment of surface water quality according to the relevant categories " for the period before and after the water exchange in the Dnipro-Donbas canal. It is established that the main indicators that impair the quality of water in this channel are the increased content of sulfates (category 7) and the magnitude of the transparency index (6-7 categories). According to the indicators of water, they are characterized as "bad» and "very bad", and by degree of purity as "dirty" and "very dirty". 